\title{
Activity Theory used as an Analytical Lens for Business Research
}

\author{
Raphael Kamanga ${ }^{1}$, Patricia (Trish) M Alexander ${ }^{1}$ and Fredrick Kanobe ${ }^{2}$ \\ ${ }^{1}$ University of South Africa, Pretoria, South Africa \\ ${ }^{2}$ Tshwane University of Technology, Pretoria, South Africa \\ Alexanderpatricia92@gmail.com
}

DOI: 10.34190/ JBRM.17.4.002

\begin{abstract}
Activity Theory is used in this paper to demonstrate the process of critical analysis of qualitative data from two case studies. The paper explains the elements of an activity system (the subject, object, outcome, mediating tools, rules, community and division of labour). Thereafter, practical examples from the work of two recent PhD students are used to show the importance of identifying and analysing activities that are found either in the introduction or the current use of information systems in business organisations. These examples highlight the applicability of Activity Theory in analysing data from projects of interest to Business Management whose topics and contexts are very different. The first focusses on the introduction of an Accounting Information System to microbusinesses in a low-income community in South Africa and the second focusses on Information Security Management in Mobile Network Organisations in Uganda. The examples illustrate the value of Activity Theory as a lens and as a way of stimulating critical analysis. Activity Theory is known for its ability to identify reasons for failure or disappointing performance in existing situations by highlighting contradictions either between different activities, between an earlier version of an activity and a later version as the activity evolves, or within an activity (between the elements of that activity). However, as shown in the first example, it can also be seen as a useful tool when proposing a new project as a predictor of success. Despite the fact that data is typically qualitative, the analytical process related to Activity Theory can be structured, which assists novice researchers or those unaccustomed to interpretivist analysis to uncover insights that are not immediately obvious. Activity Theory is said to act as a lens in data analysis and is particularly useful in organisational sciences for the theorization of technology-mediated organizational change.
\end{abstract}

Keywords: Activity Theory, contradictions, analysis of qualitative data, technology-mediated organisational change, Accounting Information Systems, Information Security Management, participative action research, case study

\section{Introduction}

This paper explains how Activity Theory (AT) can be used as a research methodology in organisational and management sciences research particularly related to organisational change. It is of particular value in research that focusses on the introduction or use of a tool or artefact to mediate a business activity or a series of activities, and to trigger organisational change related to the introduction of information and communication technology (ICT)(i.e. technology-mediated organisational change). As will be explained in the literature review, the tool need not be a physical instrument or related to ICT. However, in this paper both examples involve the introduction and use of ICT in different ways. The two examples (case studies) come from recently completed research and are used to highlight differences in the way that AT can be used and how AT adds value. It is important to note, therefore, that the paper does not focus on the findings of these studies but rather uses them to illustrate the use of AT as a supporting research methodology and, in particular, as an analytical lens. The first case study involved the facilitated adoption of an Accounting Information System by three microbusinesses operating in a so-called 'township' (low-income suburb) within a large city in South Africa. The second case study undertook a critical analysis of the management of information security of existing mobile money systems in mobile network organisations in Uganda. The literature review explains the theory and its value to Business Management research which involves the adoption and use of ICT. References have been limited to the classic papers of major contributors to AT and to recent papers.

The primary objective for this paper is to explain Activity Theory (AT) can be used as a research methodology in organisational and management sciences research.

Secondary objectives are to demonstrate how AT can:

- facilitate critical analysis of qualitative data

- provide insights into organisational change resulting from the introduction of a tool or artefact to mediate a business activity or a series of activities

- be of value in projects whose topics and contexts are very different 
Raphael Kamanga, Patricia (Trish) M Alexander and Fredrick Kanobe

- be used in conjunction with participative action research but also in a descriptive case study

\section{Literature review}

\subsection{Overview}

AT was initially developed in the Soviet Union in the 1920's and 1930's by Russian psychologists Vygotsky, Rubinshtein and Leont'ev as an approach to psychology that unites human consciousness and human activity (Hasan and Kazlauskas, 2014). Vygotsky should be recognised as the founder of AT, not just because he identified artefact- (or tool-) mediated action as the main unit of activity, but because his concept of artefactmediation allowed him to develop a theory in which the object-concept is an important and deliberate outcome of each activity (Barab, Evans and Baek, 2004). In other words, the basic element of AT, the activity, is purposeful and is carried out as meaningful and deliberate actions by the subject in order to achieve the object and outcome using physical or psychological tools, including language, in a social environment (Hasan and Kazlauskas, 2014). Hashim and Jones (2007, p. 2) define AT as "...a theoretical framework for analysis and understanding of human interaction through their use of tools and artefacts." An activity both facilitates, and is facilitated by the tool used. AT is also described as being a philosophical and cross-disciplinary framework that is useful for studying both the individual and social levels, which are interlinked in different forms of human practices as developmental processes (Kuutti, 1996). Nardi (1996) describes AT as "a powerful and clarifying descriptive tool", providing a set of basic theoretical concepts to help understand the relationship between the human mind (consciousness) and activity (what people do). Activity is holistic, high level, collaborative and constructive, for example, undertaking a work project (Spinuzzi, 2014; Stuart, 2014; White and Cicmil, 2016).

\subsection{The activity system}

AT has an associated framework that assists researchers in analysing, studying, designing, describing and understanding how and why activities happened. This theory-based conceptual framework has a basic set of principles (see Section 2.6) and allows the researcher to inquire about and to explain phenomena and human activities that are of interest. It provides a cultural, historical and theoretical focus on human activity and, hence, Cultural Historical Activity Theory (CHAT) is an alternative name for Activity Theory (Hasan and Kazlauskas, 2014).

Barab, Evans and Baek (2004) explain that Vygotsky (1978) introduced the initial concept of mediated action as having three elements, namely, the subject, tool and object. The subject is engaged in an activity and this is mediated by tools to achieve a certain object. The focus of the activity is the object and the purpose of the subject is to engage in an activity (Hasan and Kazlauskas, 2014). In addition, Vygotsky saw human activity as quite distinct from that of non-human entities in that it is mediated by tools, the most significant of which is language.

"Activities are object-oriented, meaning that the most important element of the activity is the object." (Karanasios and Allen, 2018, p. 136). These same authors describe the object as the problem situation, the 'thing' that people are working on to transform or as the focus of the activity. Since the objects are so important, an activity is meaningless on its own. The object is turned into an outcome by the work process of the activity (White and Cicmil, 2016). In AT, the subject (human doer) and the object (things being transformed) form the core of the activity and the eventual outcome of the activity can be either intended or unintended (Hasan and Kazlauskas, 2014).

People are innovative and hence constantly change the objects and create new objects. A social understanding of the changing character of these objects, which is facilitated by AT, enables it to be particularly relevant and strengthens its ability to contribute to the community in which it is located. The new objects are normally a consequence of unplanned and multiple activities and the transformed object will in turn often bring about changes in the behaviour of the subject. However, it is not only the subject, but the environment and even the tool that is modified through mediated activity (Engeström, 1999).

Despite the fact that activities are object-oriented, the role of tools in an activity system is central to AT. Tools are artefacts or systems (such as language) that are created as a result of a social process and previous activities. In research, particularly that involving the introduction or use of ICT or information systems, AT recognises that cultural characteristics are 'designed into' tools and hence the social and the technical aspects 
are combined. However, unfortunately in many studies an emphasis is placed on technology for its ability to transform an activity (Karanasios, 2014a).

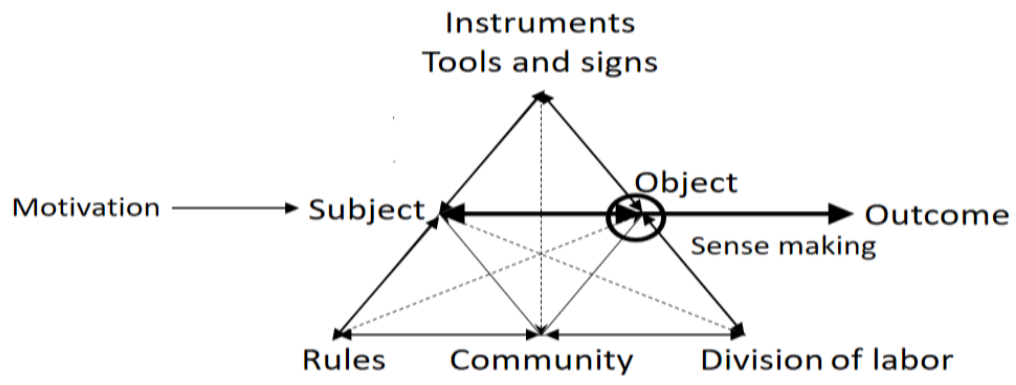

Figure 1: The main elements of the activity system (Adapted from Engeström (2010))

Engeström proposed an extended Activity Systems model (See Figure 1) that emphasizes the collective nature of a human activity as he recognised that human work is done in a social and cultural context (Engeström, 2010). Hence, the extended model adds a community component, rules (an accumulation of knowledge about how to do something) and the division of labour. Karanasios and Allen (2018) propose that motivation be added to the model as a concept feeding into the subject element (See Figure 1). There are relationships between each of the elements. Hence, an activity system is made up of tightly related elements; it is holistic rather than a collection of independent parts.

Rules and norms govern the use of tools. However, tools (including technology) may influence and transform the rules and norms resulting in dynamic activity systems. Since, over time the object of the system may change and manifest itself in different ways, new ways of working are introduced which may create new divisions of labour with new efficiencies and new types of labour. A division of labour naturally implies differences of status (Engeström, 1987 cited by Kizito, 2015). This may be caused by physiological factors, cultural conflicts or increases in population, by-laws, or any of many other factors. The division of labour means that activities do not occur in isolation and thus need to be understood within their environmental context.

\subsection{Hierarchical structure of activity, actions and operations}

A separate addition to AT is a three-level model for structuring an activity (Barab, Evans and Baek, 2004). Since some studies require a more detailed investigation than at the level of an activity, a hierarchical structure was proposed in which the top level, the activity, is motive driven and is composed of goal-directed actions and the actions themselves are composed of operations (Barab, Evans and Baek, 2004 citing Leont'ev, 1978). The motive of the individual activity is to transform the object in order to achieve an anticipated outcome. At the action level, the aim is contained in the object itself and is to achieve a certain goal. It is difficult to clearly define an object, meaning that it might be interpreted differently by different people or might change.

Lektorsky (2009) argues that the values and norms of an activity should be taken into account in order to understand collective activity in terms of its actions, operations, motives, goals and tasks. However, the distinction between an action and an activity can become blurred. An operation is generally regarded as a process whereby incoming resources are transformed into out-going products / services by a series of activities or sub-processes.

\subsection{The work activity}

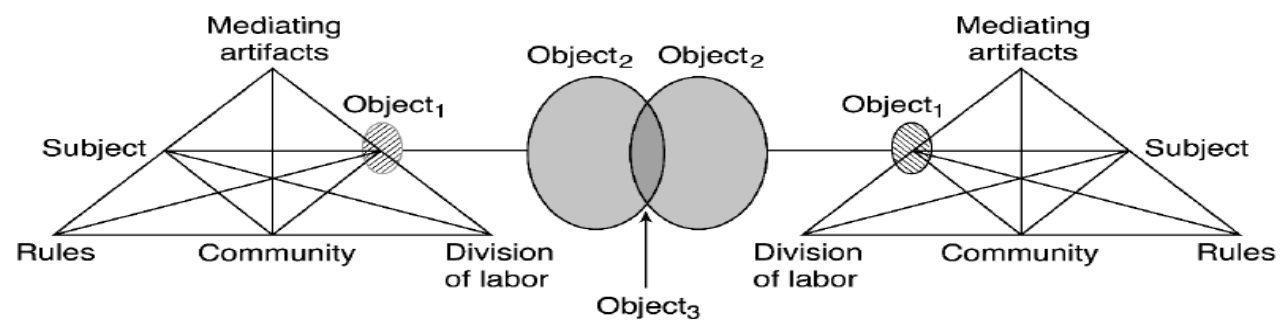

Figure 2: Third Generation of Activity (Engeström, 2001) 
The third generation of the Activity Theory entails joint activity or practice being the unit of analysis rather than an individual activity as there may be several systems exhibiting patterns of contradiction and tension at the same time (Engeström, 1999). Figure 2 is a minimal representation of two concurrent activity systems (as provided by Engeström (2001)), however the objects (labelled Object 1 and Object 2 for both activity systems in Figure 2) need not be identical for the two activities, although in some cases they are. The model also takes into account that several subjects can have common interests (Object 3 in Figure 2). Adopting this approach, an activity is best understood when it is seen in the context of other individuals' (subjects') actions, as these may impact on one another and may coincide to some extent. Each activity has its owner or subject. In addition, the outcome of one activity is often intended for some other activity; the outcome in one activity may become an object, or actor in a subsequent activity (Korpela, Mursu and Soriyan, 2002). Hence, activities are independent but un-isolated units that are influenced by the environment and other activities and this may cause contradictions (Adams, Edmond and Hofstede, 2003; Engeström, 2010) (Engeström, 2010).

For a collective activity there is a collective subject, and for an individual activity there is an individual subject. Although a collective activity cannot happen without more than one individual participating as part of the subject, the collective activity does not completely determine individual actions - each individual is a free agent with his or her own goals and ideas. Hence, individuals can resist new or existing norms and rules in order to form other ones, which makes it difficult to predict their behaviour (Lektorsky, 2009). Korpela et al. (2002) identify a "work activity" as a form of a collective activity, which comprises of people working in an organised way. The motives for a collective work activity may vary for each of the participants but all intend to transform the shared object so as to produce the collective outcome (Karanasios and Allen, 2018). The actors do not need to be working at the same time or place and play different roles (at the lower level of the hierarchy of activity-action-operation and, hence, these are "individual actions") in transforming the object to the outcome (Korpela, Mursu and Soriyan, 2002).

For the individual action to succeed within a work activity, coordination and communication between the separate actions is required. Since the individual subject is within a community, there have to be shared rules governing the multiple relationships between the elements of the whole activity system. This view makes AT particularly relevant to organisational sciences and business management.

\subsection{Contradictions}

An activity system has several levels of contradictions that must be identified and analysed in order to better understand how, when, and why an activity system develops. The primary contradiction is the basic source of instability and development and is found within any of the nodes or elements of an activity system (Barab, Evans and Baek, 2004; Foot, 2014). Secondary contradictions refer to a conflict between two different nodes of the activity system (Barab, Evans and Baek, 2004; Foot, 2014). Other contradictions may occur between the object and outcome of a single activity system and between separate activity systems (Mursu, Soriyan and Korpela, 2003; Mursu et al., 2007).

Contradictions shape and change the way things are done (Karanasios, 2014a). They generate disturbances and conflicts, but also generate innovation. Activity systems are constantly working through contradictions and, hence, are virtual disturbance- and innovation-producing machines. In activity systems, equilibrium is an exception and tensions, disturbances, and local innovations are the engine of change.

\subsection{Summary of AT}

Engestrom (2001) formulated five principles of Activity Theory. Firstly, the main unit of analysis in Activity Theory is the activity system. Secondly, 'multi-voicedness' is a cause of contradictions. Thirdly, the principle of historicity argues that the history of an activity system helps researchers to understand the problems as well as the potentials because "parts of older phases of activities stay often embedded in them as they develop".

Fourthly, contradictions can result in tensions but also transformation in activity systems. This links with the second principle, as the multi-voicedness is often the source of the contradictions. In a context of a mobile health system, for example, Allen, Brown, Karanasios and Norman (2013, p. 844) found "a major contradiction between the subject of the system (the paramedics/ambulance crew) and the division of labor relating to the delivery of the drug". Finally, expansive learning relates to the possibility of major transformations in activity systems through re-conceptualisation of the object and the motive of activity embracing a radically wider horizon of possibilities than in the previous mode of the activity. 
Although research using AT is best understood as a developing body of knowledge, there are some basic characteristics of activity systems and research using AT that are recognised. Hardman (2005) draws primarily from Cole and Engestrom (1993) and Russell (2002) in order to elaborate these ideas.

1. Human activity is collective and human behaviour originates within the social realm.

2. Tools, which carry socio-historical meanings, mediate activities.

3. AT studies development and change, which is understood to include historical change, organisational change, individual development and moment-to-moment change.

4. AT assumes that people are active and knowing agents but that they act in sites that are not necessarily of their choosing with tools that constrain and afford their actions.

5. Methodologically, AT emphasises the emergent nature of activity and acknowledges a central role for interpretation, i.e. interpretivism, in its explanatory framework. Consequently, activity theorists make use of contextualist methodologies.

6. Activity systems are constantly subject to change and AT sees these changes as driven by contradictions. Contradictions can arise within and between systems.

\subsection{AT in Research}

AT has been used extensively in education research as well as in social science, anthropology and work science. Today it is recognised as a multidisciplinary research approach, which is increasingly oriented toward the study of technological and human aspects within organisations and social systems (Nardi, 1996; Barab, Evans and Baek, 2004; White and Cicmil, 2016). Recent examples of use reported in organisational and business sciences and published in various 'business journals' include its use for business intelligence (Kekwaletswe and Lesole, 2016), knowledge acquisition through process mapping (White and Cicmil, 2016) and the creation and evolution of new business ventures (Jones and Holt, 2008). The value of integrating AT into organisation studies, particularly those relating to organisational change and technology-mediated change has been noted (Harrington and Kearney, 2011; Kang and Hovav, 2018).

Karanasios (2018) refers to Blackler (2009) when saying, "In the context of organizational research rather than the organizational being taken as the unit of analysis and organizational objectives prioritized, activity theory takes the activity system as the core unit and prioritizes 'objects' of organizational activities. This invites a situated analysis of the activity 'which is often overlooked in more abstract studies of organizations' (Blackler, 2009, p. 27)."

However, in many cases the tools used to mediate in the activity system are information systems or ICT tools and hence Information Systems (IS) journals are often selected as places to publish these papers, even when the authors are from business schools. Examples of multidisciplinary AT use related to IS and published in IS journals include those described by Weeger and Haase (2016), Clemmensen Kaptelinin and Nardi (2016), Forsgren and Byström (2018), Kelly (2018) Mursu and various co-authors (2002; 2004; 2007), Simeonova (2018) and Karanasios and Allen with co-authors (Allen et al., 2013; Karanasios and Allen, 2013; Karanasios, 2014b). Despite this, relatively few IS researchers have used AT (Malaurent and Avison, 2016).

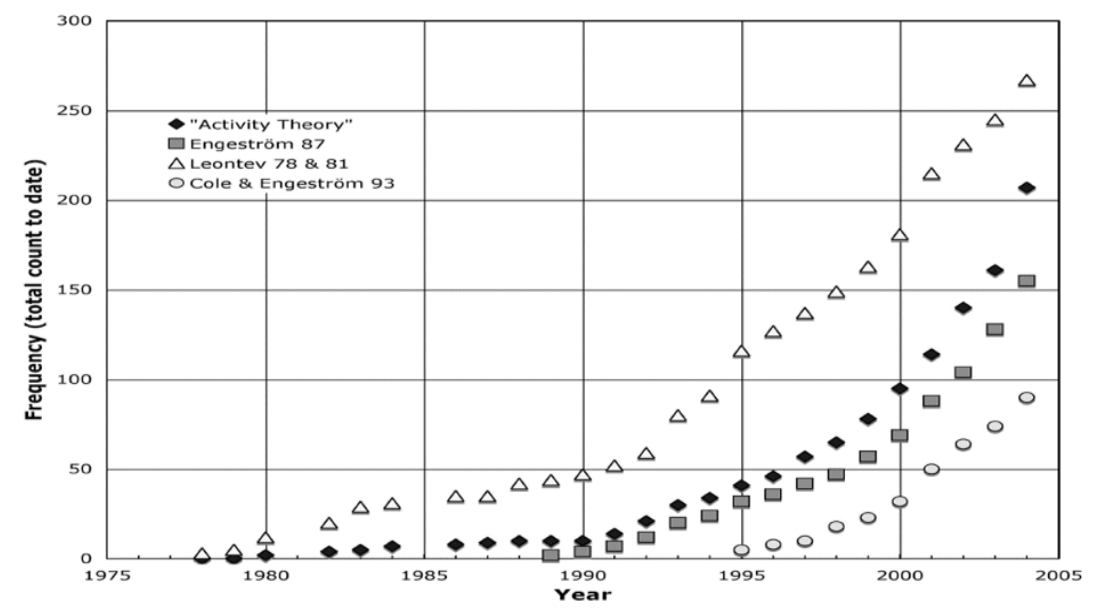

Figure 3: Indication of the Growth of Activity Theory (Roth and Lee, 2007) 
Figure 3 depicts four indicators of the increasing interest shown in Activity Theory over three decades (up to 2005), based on citation frequencies in the Institute for Scientific Information's citation database.

\subsection{Benefits of using AT as a theoretical lens}

Although there are several frameworks that use human activity systems as units of analysis (Zott and Amit, 2017; see for example Sadok and Welch, 2019), they may fail to provide a holistic analysis of real-life situations because they focus on isolated individual actions (Kuutti, 1996). AT can help to uncover contradictions and congruencies and this helps to uncover the relationships and links that are existent in a deep social system (Karanasios and Allen, 2018, p. 44). Identifying contradictions can assist researchers in explaining why a technology has not achieved its desired and expected outcomes. Contradictions help activity systems to evolve from time to time.

\subsection{Shortcomings in existing research using AT}

In a comprehensive assessment of AT and argument for its extension and use, Karanasios (2018) points out aspects of AT in IS research that generally receive insufficient attention. This subsection relies heavily on that set of recommendations.

\subsubsection{Can AT be used for research for technologies that are no longer simply tools?}

The shift in IS research continues to inspire new perspectives on the role of technology, as technology is thought to have surpassed its initial role as merely a tool as envisaged in the traditional AT (Karanasios, 2018; Karanasios and Allen, 2018). Hence the evolution of social-media to becoming a tool-community hybrid and indeed that technologies in general are "increasingly taking hold of all the aspects of the activity system" (Karanasios and Allen, 2018, p. 138). This links in some respects with the view that IS and ICT related AT research may still be over-emphasizing the role of technology (Simeonova, 2018). A few examples of papers in which AT is used to study social media do exist (see Bagarukayo et al., 2016; Forsgren and Byström, 2018).

\subsubsection{A multi-layered lens for understanding activities}

As noted in Section 2.3, using the AT framework, activities can be analysed at three levels, namely, activity, action and operation. The division helps the researcher in shifting the focus from the greater activity to finer grained actions and operations or sub-tasks. Karanasios and Allen (2018) argue that AT has the ability to "address the challenge of studying the interaction between technology and actors" (p. 439), however, these same authors note that few IS studies go to this more detailed level.

\subsubsection{The complexity and hidden nature of cultural-historical contradictions}

Karanasios (2018) says that although the concept of contradictions is fundamental in AT it is often understated. Simeonova (2018) supports this view saying that AT is often used in a simplistic way. In addition, it is often difficult to uncover such contradictions as established norm and existing power structures often resist change. Using various sources of data (multi-voicedness), various data collection methods (although qualitative data remains predominant the common sources of data used in case studies are needed), and longitudinal studies are appropriate for AT research (Malaurent \& Avison, 2016; Marcandella \& Guèye, 2018; Weeger \& Haase, 2016). As will be seen in Section 3, this was a major focus for both of the studies used as examples in the current paper. Karanasios (2018, p. 141) citing Engestrom and Sannino (2011) raises another major concern when claiming that "few scholars articulate their analytical approach to identifying contradictions". Table 1 gives some practical advice in this regard and the examples that follow in Section 3 are also intended to assist in making the analytical approach clear (Karanasios, 2018).

\subsubsection{Research methodology must include taking action}

A critical research philosophy is closely aligned with the intentions of AT as a theoretical framework and hence needs to be followed before and during data collection (Karanasios, 2018). Critical realism has also been used in conjunction with AT (Allen et al., 2013; Simeonova, 2018).

It is, therefore, not sufficient simply to identify contradictions; the research identify and carry out actions to address these contradictions (Karanasios, 2018). AT is a practice-based theory (Karanasios and Allen, 2018; Simeonova, 2018) and research often is undertaken in the natural (work) setting as a longitudinal case study (for example, Malaurent and Avison, 2016; Weeger and Haase, 2016; Marcandella and Guèye, 2018). Hence, research using AT may embrace a participative action research (PAR) model or canonical action research 
(Malaurent and Avison, 2016) with the iterative design that is required by PAR or may use a Design Science research methodology (see Kang and Hovav, 2018).

\section{Examples of data analysis using AT as a lens}

\subsection{Common factors}

Both case studies come from recent post-graduate work and both adopted the interpretivist paradigm but they were very different. The studies were exploratory but offered explanations and critique regarding the data collected. The section on Case 1 goes into some detail regarding the techniques used to analyse the data. Then Case 2 is described; the analysis was also done using thematic analysis using AT principles as was the case in Case 1). Finally a table is used assess how well these two case studies remain true to the requirements for AT research as described in the summary in the literature review.

\subsection{Case 1:}

Title: “A Facilitated Approach to Accounting Information Systems Adoption: A Case of South African Township Microenterprises"

Overview:

Research question: "How should AIS be introduced into township microenterprises to improve its chances of adoption?"

Research approach: The case study paid special attention to the social context in which it took place. The Subject, Community and Division of Labour shown in Figure 4 indicate the participants for the first activity only.

Data collection: The researcher described historical context, the entrepreneurs, microenterprises and the community that participated in the study. In order to add to the rich picture of the social context, the researcher included an As-Is synopsis and a high-level SWOT analysis of each microenterprise before the participative action research started. The entrepreneurs were also asked questions about themselves in individual interviews and profiles about them were presented in the study.

Data Analysis using AT as a lens: The researcher identified two key human activities in the facilitated adoption of AIS by entrepreneurs of microenterprises in the township. These were the learning and implementation of AIS within the microenterprises and included iterative cycles within and between the activities. The second of these activities is shown in Figure 4.

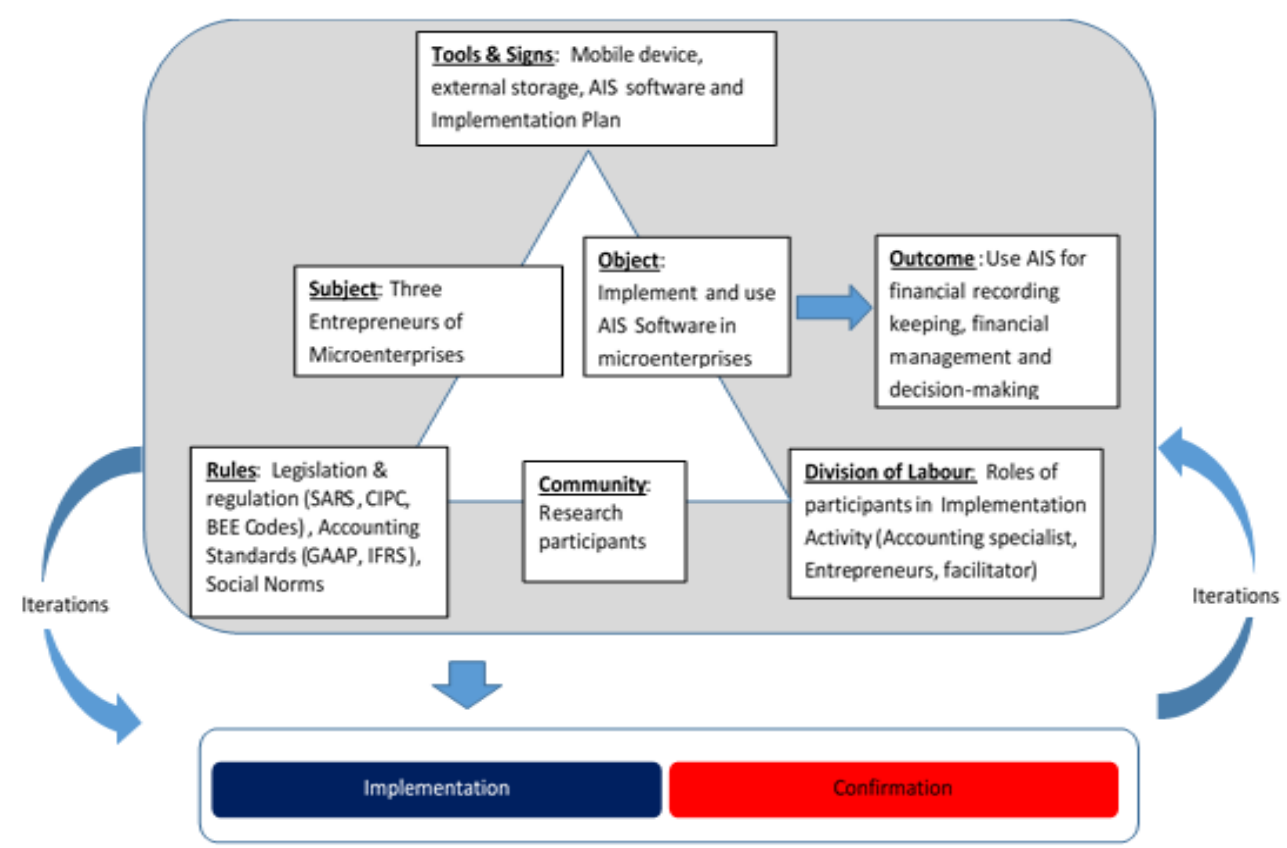

TWO STAGES OF THEINNOVATION-DECISION PROCESS

Figure 4: Analysis of the Implementation Activity System 
The research was designed around these two human activities. The researcher recorded interviews using a mobile phone as well as written notes. At the end of each iteration of the activity, the researcher identified meaningful units of data and coded it according to the elements of the activity system as shown. The activities were analysed separately and then together. In the analysis, contradictions were identified and captured in comparison matrices (See Table 2). Each activity system had a comparison matrix and therefore three matrices were completed (for the Learning Activity System, for the Implementation Activity System and the third for the comparison between the two activity systems). The researcher and participants attempted to resolve the contradictions identified in order to facilitate the adoption of AIS. The same matrix was subsequently used for identifying strengths as in addition to the contradictions, particularly strong relationships between the elements of the implementation activity system were identified.

Table 2: Comparison (Analysis) Matrix of the AIS Implementation Activity

\begin{tabular}{|c|c|c|c|c|c|c|}
\hline & Subject & $\begin{array}{l}\text { Tools and } \\
\text { Signs }\end{array}$ & Object & $\begin{array}{l}\text { Division of } \\
\text { labour }\end{array}$ & Community & Rules \\
\hline Who or what & $\begin{array}{l}3 \\
\text { entrepreneurs } \\
\text { of } \\
\text { microenterpris } \\
\text { es }\end{array}$ & $\begin{array}{l}\text { Mobile device, } \\
\text { external } \\
\text { storage, AIS } \\
\text { software and } \\
\text { implementatio } \\
\text { n plan }\end{array}$ & $\begin{array}{l}\text { Implementing } \\
\text { and using AIS }\end{array}$ & $\begin{array}{l}\text { Roles in the } \\
\text { implementatio } \\
n \text { activity }\end{array}$ & $\begin{array}{l}\text { Research } \\
\text { participants }\end{array}$ & $\begin{array}{l}\text { Legislation, } \\
\text { regulations, } \\
\text { practices and } \\
\text { norms }\end{array}$ \\
\hline \multirow[t]{2}{*}{ Subject } & & \multirow[b]{2}{*}{ Strength } & \multirow[t]{2}{*}{ Contradiction } & & \multirow[b]{2}{*}{ Strength } & Contradiction \\
\hline & & & & & & Strength \\
\hline \multicolumn{7}{|l|}{$\begin{array}{l}\text { Tools } \\
\text { \& Signs }\end{array}$} \\
\hline Object & & & & Contradiction & & Contradiction \\
\hline \multirow[t]{2}{*}{$\begin{array}{l}\text { Division of } \\
\text { Labour }\end{array}$} & & & & & Contradiction & \\
\hline & & & & & No strength & \\
\hline Community & & & & & & No strength \\
\hline Rules & & & & & & \\
\hline
\end{tabular}

Contradictions were identified in the Implementation Activity for each of the pairs of action system elements. However, in this paper only some examples that illustrate particular points have been selected and are shown as blue blocks in Table 2 . These are described together with the steps taken to address them.

- Subject-Object Contradiction: Entrepreneurs were not always able to capture transactions in the AIS as they occurred and they would forget to capture transactions later. They also did not stick to the backup schedule. Old habits were difficult to overcome.

- Resolution: The researcher and accounting specialist re-enforced the message that entrepreneurs needed to have the discipline and commitment to capture transactions and back up data according to the schedule.

- Subject-Rule Contradiction: a) The entrepreneurs were not completely comfortable with revealing their financial data. They were not completely transparent to the accounting specialist and facilitator.

- Resolution: The entrepreneur has to be encouraged to be more transparent since there was an ethical (non-disclosure) undertaking to keep their information private in the research.

- Contradiction: b) The entrepreneurs continued informal practices like borrowing money from Mashonisas (informal money-lenders).

- No resolution: The entrepreneurs could not get credit from banks.

- Object-Division of Labour Contradiction: The entrepreneurs preferred personal support to online support of AIS software.

- No resolution: This could not be resolved as the technical support for the free, open-source software was only available online. Over time, partly through necessity and partly through increased trust, they were expected to use the Internet. 
- Object-Rule Contradiction: The implementation of AIS did not immediately change the participants' social norms and practices. Some informal practices persisted

- Resolution: Implementation of the AIS will only have an effect on the entrepreneurs' social norms after some time.

- Division of Labour-Community Contradiction: The entrepreneurs wanted to focus on business and maybe accounting, compliance and support but they could not afford it.

- Resolution: The objective of the study was to empower and encourage the entrepreneurs to do the basic bookkeeping themselves until they could afford professional services.

Strengths could not be identified for every one of the pairs of action system elements in the Implementation Activity. However, examples that illustrate particular points have been selected and are shown as yellow blocks in Table 2. These are described together with the positive effect of these strengths on the project.

- Subject-Tool Strength Identified: The entrepreneurs were already familiar with and had fully adopted mobile devices and applications before the study. This made the AIS implementation faster and easier.

- Subject-Community Strength Identified: The accounting specialist came from same community as the entrepreneurs. Hence, the entrepreneurs were able to identify with her. The entrepreneurs are more likely to trust one of their own.

- Subject-Rules Strength Identified: The entrepreneurs were well-versed in the norms and business practices in the community of Alexandra.

- Division of Labour-Community Strength Identified No strength identified. This is weakness because there is a lack expertise or professionals to assist small businesses in the township.

- Community-Rules: No Strength identified. Small business in the township community mostly ignore regulations and proper business practices

\subsection{Case 2:}

Title: "Information Security Management Framework for Mobile Money Systems in Uganda"

Overview: Mobile money systems are generally accepted in Uganda as an easy way to make emergency payments and do electronic money transfers but there are a number of oversight information security management issues (insufficient information security policies, procedures and practices) that need to be addressed. Previous studies have focused on objective security (technical applications and solutions) but have not paid attention to the subjective aspects of information security management. Technical solutions alone cannot fully solve this problem.

Research objective: To develop an information security management framework that will help to minimize the identified information security management problems in mobile money systems in Uganda (More details can be found in Kanobe, Alexander and Bwalya, 2017)

Research approach: This study adopted the interpretivist paradigm in order to explore the topic and get an indepth understanding of the information security management problem in mobile money systems using Uganda as a case study. Data collection occurred between August and November 2017.

Data collection and analysis: In order to better understand the information security management of mobile money systems in Uganda, a qualitative case study was undertaken involving three Mobile Network Operators (MNOs). The mobile money information security management framework was developed and validated. Key data methods employed were internal documents review and semi-structured interviews involving managers across various departments involved in mobile money information security management such as, IT, internal audit, legal affairs, human resource, security and compliance, legal affairs and many more. Participants with expertise knowledge in the area of study were needed, therefore, the study participants were purposively selected.

Data Analysis using AT as a lens: Information security management involves several activities and, hence, Activity Theory (AT) was utilized to underpin the study through all its research process. The contradictions were identified during the analysis and interpretation of the data and review of related literature. 


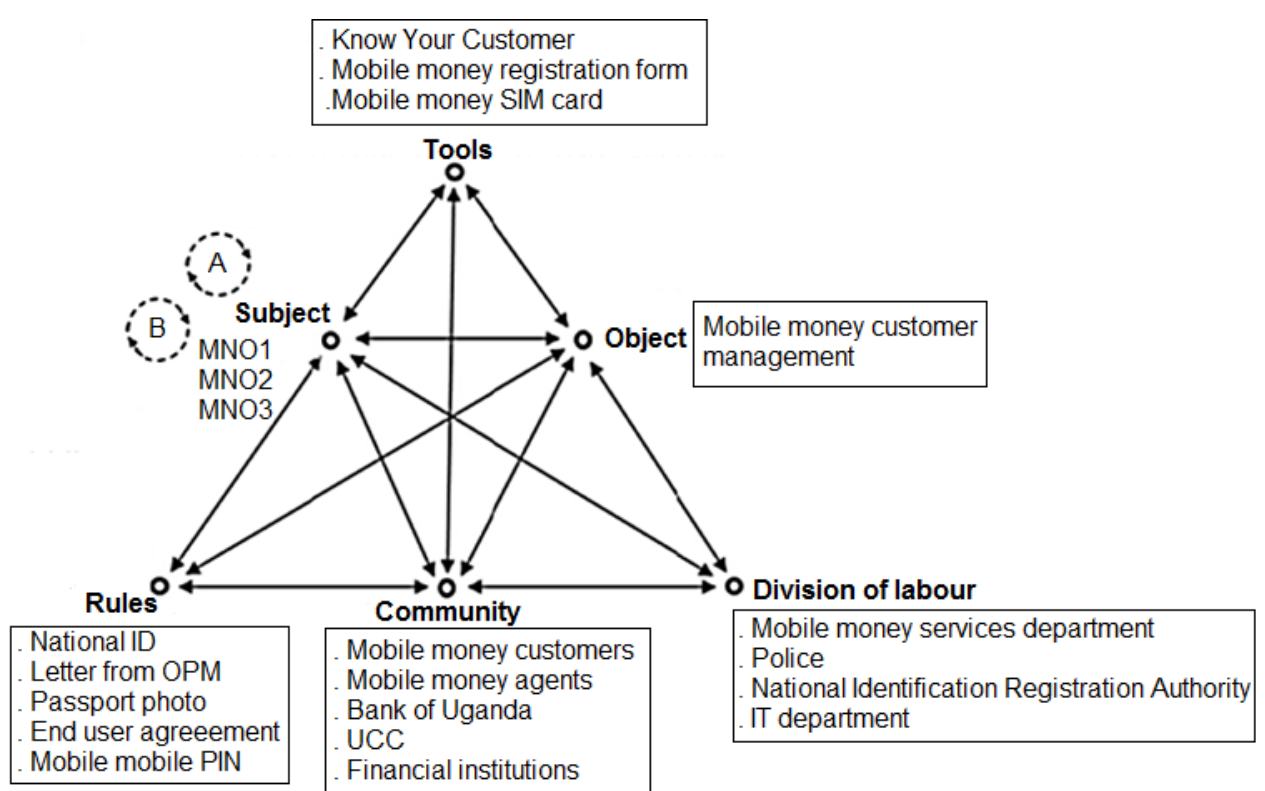

Figure 5: Primary information security management contradictions in the Mobile Network Operators' activity system (Source: data)

Explanations of the primary contradictions, labelled A and B in Figure 5, are presented in Table 3.

Table 3: Description of the primary contradictions

\begin{tabular}{|l|l|}
\hline Contradiction & Description \\
\hline A & $\begin{array}{l}\text { The MNOs' mobile money application administrators are also end-users of the mobile } \\
\text { money system they are administering. Operating as system administrators and users of the } \\
\text { same system requires tight policies to minimise system abuse (subject vs. subject) }\end{array}$ \\
\hline B & $\begin{array}{l}\text { Mobile money system administrators report mobile money abuse to MNO management. } \\
\text { However, mobile money system administrators are also end-users of the system so } \\
\text { reporting themselves remains a challenge and increases risks of mobile money abuse by } \\
\text { MNOs. (subject vs. subject) }\end{array}$ \\
\hline
\end{tabular}

The secondary contradictions develop between different mobile money activities nodes are shown in Figure 6. They are labelled alphabetically and described in Table 4.

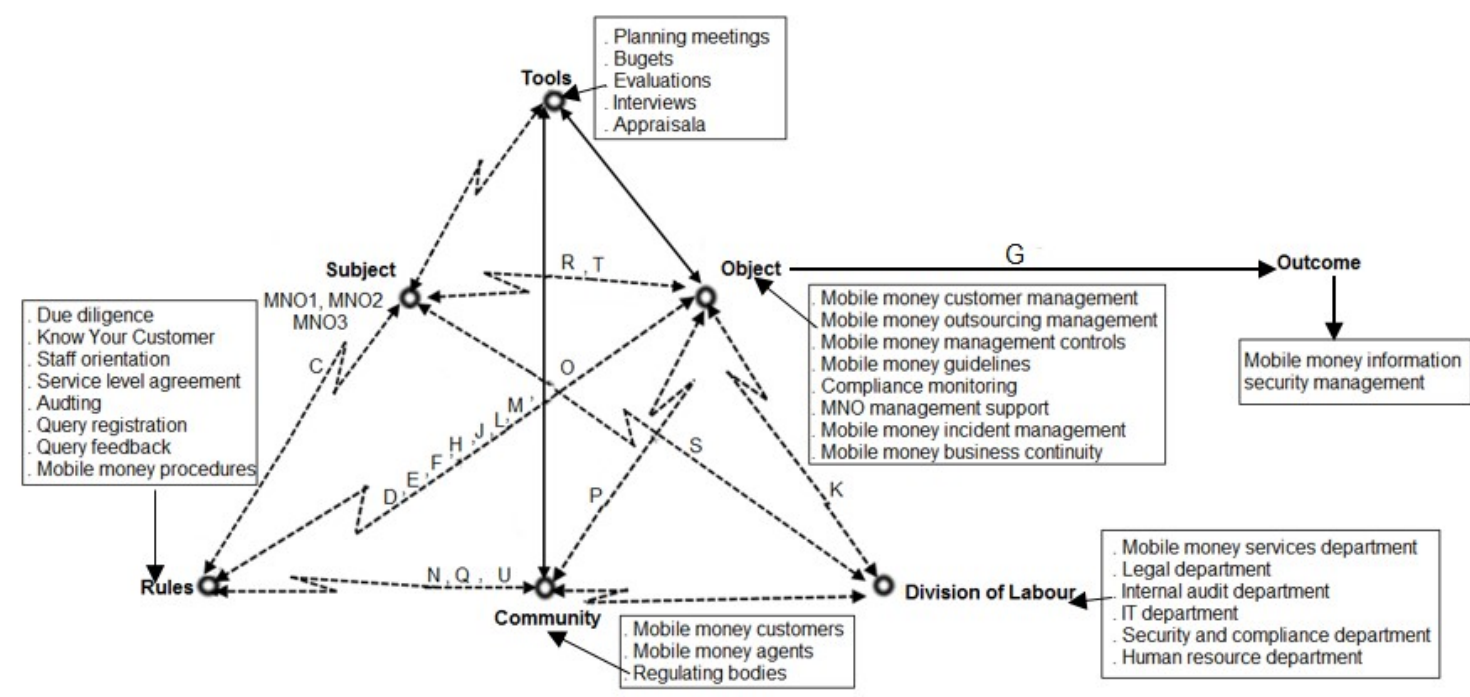

Figure 6: Secondary information security management contradictions in the Mobile Network Operators' activity system (Source: data) 
Table 4: Descriptions of the secondary contradictions in the mobile money activity system

\begin{tabular}{|c|c|}
\hline Contradiction & Description \\
\hline C & $\begin{array}{l}\text { The mobile money customers' registration is mandatory for all users of mobile money } \\
\text { systems but at the same time the mobile money system still has an option for unregistered } \\
\text { mobile money users. Leaving the unregistered option in the mobile money system provides } \\
\text { an opportunity for unregistered mobile money users to access the system. (Tools vs. } \\
\text { Rules). }\end{array}$ \\
\hline $\mathrm{D}$ & $\begin{array}{l}\text { The rules followed to appoint outsourced mobile money agents are insufficient to ensure the } \\
\text { maximum possible safety of mobile money information in the hands of third parties. The } \\
\text { mobile money due diligence rules include providing a bank statement, business registration } \\
\text { certificate, physical address, bank account with financial institution and National ID. (Rules } \\
\text { vs. Object). }\end{array}$ \\
\hline $\mathrm{E}$ & $\begin{array}{l}\text { The mobile money agents' service level contracts are not comprehensive enough to address } \\
\text { information security management concerns in mobile money systems. (Rules vs. Object). }\end{array}$ \\
\hline $\mathrm{F}$ & $\begin{array}{l}\text { There was evidence of inadequate rules to be followed to raise information security } \\
\text { awareness (object). Information security awareness activity is confined to PIN sensitization, } \\
\text { occasional email alerts and SMS, leaving out many other rules. (Rules vs. Object). }\end{array}$ \\
\hline G & $\begin{array}{l}\text { Information security management has not been integrated into the mission and vision of the } \\
\text { MNOs. The absence of explicit references to information security in the MNOs' strategic } \\
\text { goals reflects a low priority given to information security management of mobile money } \\
\text { systems among MNOs. (Object vs. Outcome). }\end{array}$ \\
\hline $\mathrm{H}$ & $\begin{array}{l}\text { There was evidence of insufficient management information security controls which are } \\
\text { expected of a system that involves many money transactions. (Rules vs. Object). }\end{array}$ \\
\hline I & $\begin{array}{l}\text { The development of Mobile Money Guidelines lacks division of labour. The guidelines were } \\
\text { developed only by Bank of Uganda without participation of other mobile money regulating } \\
\text { bodies. (Community vs. Division of labour). }\end{array}$ \\
\hline $\mathrm{J}$ & $\begin{array}{l}\text { There was a lack of a comprehensive information security policy that defines the 'dos and } \\
\text { don'ts' of mobile money information security and repercussions for failing to comply with the } \\
\text { expected guidelines. (Rules vs. Object). The Uganda mobile money guidelines } 2013 \text { are } \\
\text { short of sanctions. }\end{array}$ \\
\hline K & $\begin{array}{l}\text { One of the rules for mobile money agents as per the Mobile Money Guidelines is providing } \\
\text { qualified supportive staff at their centers. However, this rule is not followed by MNOs during } \\
\text { mobile money agents' recruitment. (Division of labour vs. Object). }\end{array}$ \\
\hline $\mathrm{L}$ & $\begin{array}{l}\text { One of the rules for mobile money agents is being a registered limited company. However, } \\
\text { the scope of the company and area of specialty for the limited company are not defined. } \\
\text { This opens a door for any registered limited company, irrespective of its scope of activities, } \\
\text { to qualify as a mobile money agent. (Rule vs. Object). }\end{array}$ \\
\hline M & $\begin{array}{l}\text { Some aspects of the due diligence conducted regarding mobile money agents are not } \\
\text { specific and there is a risk of mobile money information with entities that lack expertise in } \\
\text { mobile money business. For example, the requirement for proving qualified staff. } \\
\text { Qualification is a multi-dimension factor which entails types and levels of qualifications. } \\
\text { Therefore, without specifying the type and level of qualification makes it open to any } \\
\text { qualified staff from any field, yet mobile money requires specific qualifications related to } \\
\text { Information Technology and e-business. (Rule vs. Object). }\end{array}$ \\
\hline $\mathrm{N}$ & $\begin{array}{l}\text { MNOs follow rules to assign roles and responsibilities. Mobile money roles are allocated } \\
\text { according to qualification, implying division of labour. However, there is limited segregation } \\
\text { of duties. For example, in MNO1, the IT manager also executes the duties of information } \\
\text { security personnel which can lead to system compromise. (Rules vs. Division of labour). }\end{array}$ \\
\hline $\mathrm{O}$ & $\begin{array}{l}\text { Study findings revealed that a single outsourced mobile money application developer does } \\
\text { all the tasks around mobile money application development. This discloses insufficient } \\
\text { controls, auditing and monitoring of the mobile money application development processes } \\
\text { and hence increases opportunities for system comprise. }\end{array}$ \\
\hline $\mathrm{P}$ & $\begin{array}{l}\text { There was evidence of inadequate compliance monitoring of the outsourced mobile money } \\
\text { agents. Mobile money agents are third parties who get access to mobile money customers' } \\
\text { information right from account opening to mobile money transactions, hence it requires tight } \\
\text { monitoring to minimise system abuse. The insufficient monitoring of the mobile money } \\
\text { agents' activities leaves mobile money customers' information susceptible to information } \\
\text { security abuse. (Object vs. Community) }\end{array}$ \\
\hline
\end{tabular}




\begin{tabular}{|l|l|}
\hline Contradiction & Description \\
\hline $\mathrm{Q}$ & $\begin{array}{l}\text { There was evidence of attempts to manage mobile money systems using old Mobile Money } \\
\text { Guidelines. The current Mobile Money Guidelines were developed in } 2013 \text { (five years before } \\
\text { this study) and there was no evidence of plans or a schedule for reviewing those guidelines, } \\
\text { yet information security management is a dynamic field that calls for careful review of } \\
\text { approaches and strategies. The old regulation guidelines may not be effective for } \\
\text { dramatically new trends in technology and corresponding changes in information security } \\
\text { management. (Rules vs. Community). }\end{array}$ \\
\hline $\mathrm{R}$ & $\begin{array}{l}\text { There was evidence of insufficient management support from MNOs for information security } \\
\text { awareness. Information security awareness by information security experts is taken to be } \\
\text { the first defensive wall for information security management. When people are aware of the } \\
\text { consequences of their actions they tend to be careful and avoid making mistakes that can } \\
\text { lead to system compromise. (Subject vs. Object). }\end{array}$ \\
\hline $\mathrm{S}$ & $\begin{array}{l}\text { There was evidence of inadequate management of mobile money security incidents among } \\
\text { the MNOs. One, general, hot-line was used for reporting mobile money incidents (both } \\
\text { operational issues and security cases) resulting in long response times and, hence, } \\
\text { increasing the severity of risks related to mobile money security management issues. } \\
\text { (Subject vs. Division of labour). }\end{array}$ \\
\hline $\mathrm{T}$ & $\begin{array}{l}\text { Study findings revealed that continuity business plans and recovery programs exist among } \\
\text { MNOs. However, these lack adequate support in terms of training, awareness, resources } \\
\text { and reviews, rendering them inadequate for the current needs of mobile money service } \\
\text { continuity and safety of mobile money information. (Subject vs. object). }\end{array}$ \\
\hline $\mathrm{U}$ & $\begin{array}{l}\text { The study disclosed that the MNO internal policy development process was dominated by a } \\
\text { limited number of departments, namely Law and Internal Audit. Not involving other } \\
\text { departments is tantamount to a lack of policy ownership and accountability among the } \\
\text { excluded departments. (Rules vs. Division of labour). }\end{array}$ \\
\hline
\end{tabular}

The study concludes that the rules, tools, community and division of labour employed by the subjects (MNOs) to attain improve the objects are wanting and necessitate continuous review and update because mobile money systems like any other technology are dynamic. The PDCA (Plan, Do, Check, Act) approach to mobile money information security management activities is recommended in order to address update information security concerns for MNOs.

\section{Discussion}

Table 5 is used to illustrate the different ways in which AT was used in these two case studies and whether the studies were aligned to the principles and guidelines proposed by proposed by Engestrom (2001), Hardman (2005) and Karanasios (2018) and others as discussed in the literature review (Section 2).

Table 5: Comparison of cases

\begin{tabular}{|c|c|c|}
\hline & Case 1 & Case 2 \\
\hline Multi-voicedness & $\begin{array}{l}\text { Yes, The voices of the researcher } \\
\text { who acted as facilitator and } \\
\text { advocate, the accounting teacher, } \\
\text { and } 3 \text { entrepreneurs were given } \\
\text { equal standing. }\end{array}$ & $\begin{array}{l}\text { Yes to some extent: A variety of } \\
\text { stakeholders employed by the } 3 \\
\text { mobile network operators (MNOs) } \\
\text { who managed the mobile money } \\
\text { applications and data were } \\
\text { interviewed. However, clients and } \\
\text { the mobile money (MM) agents } \\
\text { with whom clients interacted were } \\
\text { not interviewed or surveyed. This } \\
\text { was beyond the scope of the } \\
\text { thesis which focussed in } \\
\text { information security management } \\
\text { (ISM) policies rather than } \\
\text { operation of the MM system. }\end{array}$ \\
\hline Longitudinal case study & Yes & $\begin{array}{l}\text { No, this was a descriptive case } \\
\text { study which used the literature, } \\
\text { including information about ISM } \\
\text { policies and management in other } \\
\text { countries in central Africa, to } \\
\text { critically analyse the existing } \\
\text { situation (described during } \\
\text { interviews). }\end{array}$ \\
\hline
\end{tabular}




\begin{tabular}{|c|c|c|}
\hline & Case 1 & Case 2 \\
\hline $\begin{array}{l}\text { A holistic analysis of real-life } \\
\text { situations }\end{array}$ & $\begin{array}{l}\text { Yes, historical, cultural, social, } \\
\text { economic and business aspects } \\
\text { were included in detail }\end{array}$ & $\begin{array}{l}\text { Yes to some extent as the MNOs } \\
\text { had been in operation for several } \\
\text { years. Issues regarding rural } \\
\text { communities and their } \\
\text { vulnerability to financial data } \\
\text { mismanagement were also } \\
\text { discussed. }\end{array}$ \\
\hline $\begin{array}{l}\text { Combining active participation and } \\
\text { action research }\end{array}$ & Yes, & $\begin{array}{l}\text { No. As a descriptive case study } \\
\text { this was not possible. Although } \\
\text { there was a need for information } \\
\text { from interviewees the impression } \\
\text { was that they held back } \\
\text { confidential organisational } \\
\text { information. }\end{array}$ \\
\hline Uncovered contradictions & $\begin{array}{l}\text { Yes, contradiction between } \\
\text { elements, activities and over time } \\
\text { were identified. }\end{array}$ & $\begin{array}{l}\text { Yes, contradiction between } \\
\text { elements and activities over time } \\
\text { were identified using the } \\
\text { corresponding activities identified } \\
\text { in the literature. }\end{array}$ \\
\hline $\begin{array}{l}\text { The outcome of one activity is } \\
\text { often intended for some other } \\
\text { activity. The outcome in one } \\
\text { activity may become an object, or } \\
\text { actor in another activity (Korpela, } \\
\text { Mursu and Soriyan, 2002). }\end{array}$ & $\begin{array}{l}\text { The learning activity was followed } \\
\text { by the implementation activity. } \\
\text { Iterations occurred with amended } \\
\text { activities. }\end{array}$ & $\begin{array}{l}\text { The activities identified occurred } \\
\text { continuously and hence } \\
\text { contemporaneously. }\end{array}$ \\
\hline $\begin{array}{l}\text { Can AT be used for research for } \\
\text { technologies that are no longer } \\
\text { simply tools? }\end{array}$ & $\begin{array}{l}\text { The technology was considered } \\
\text { only to be a tool. }\end{array}$ & $\begin{array}{l}\text { The technology was considered } \\
\text { only to be a tool. }\end{array}$ \\
\hline $\begin{array}{l}\text { A multi-layered lens for } \\
\text { understanding activities }\end{array}$ & $\begin{array}{l}\text { Inspection at the level of actions } \\
\text { and operations was not done. } \\
\text { However, the contradictions } \\
\text { generally identified operational } \\
\text { level challenges and hence } \\
\text { amendments were at a level of } \\
\text { detail. }\end{array}$ & $\begin{array}{l}\text { Inspection at the level of actions } \\
\text { and operations was not done } \\
\text { explicitly. However, the } \\
\text { contradictions generally identified } \\
\text { operational level. }\end{array}$ \\
\hline $\begin{array}{l}\text { The complexity and hidden nature } \\
\text { of cultural-historical contradictions }\end{array}$ & $\begin{array}{l}\text { Yes. A critical approach was } \\
\text { evident (although critical realism } \\
\text { was the espoused epistemology). } \\
\text { The intention was to empower the } \\
\text { entrepreneurs. }\end{array}$ & $\begin{array}{l}\text { The data collection process was } \\
\text { limited by organisational } \\
\text { confidentiality. }\end{array}$ \\
\hline $\begin{array}{l}\text { Research methodology must } \\
\text { include taking action }\end{array}$ & $\begin{array}{l}\text { Yes, the iterations undertaken } \\
\text { were specifically intended to } \\
\text { address the contradictions that } \\
\text { were identified. }\end{array}$ & $\begin{array}{l}\text { As a descriptive case study this } \\
\text { was limited to providing the } \\
\text { organisations with the } \\
\text { recommendations together with } \\
\text { explanations in this regard. }\end{array}$ \\
\hline Uncovered congruencies & $\begin{array}{l}\text { Strong relationships } \\
\text { (congruencies) were considered } \\
\text { as important - these are the } \\
\text { strengths that were uncovered } \\
\text { that are predictors of sustained } \\
\text { change. }\end{array}$ & $\begin{array}{l}\text { In the case of the MNOs it was } \\
\text { found that there were } \\
\text { comprehensive similarities. In this } \\
\text { case these were seen as a sign of } \\
\text { lack of innovation and were } \\
\text { judged to be limiting competitive } \\
\text { advantage. }\end{array}$ \\
\hline $\begin{array}{l}\text { Human activity is collective and } \\
\text { human behaviour originates within } \\
\text { the social realm. }\end{array}$ & Yes & Yes \\
\hline $\begin{array}{l}\text { Tools, which carry cultural- } \\
\text { historical meanings, mediate } \\
\text { activities. }\end{array}$ & $\begin{array}{l}\text { The tools challenged the existing } \\
\text { cultural-historical meanings } \\
\text { (social norms) regarding } \\
\text { revelation of financial information. }\end{array}$ & $\begin{array}{l}\text { Mobile money systems are indeed } \\
\text { tools carrying socio-historical } \\
\text { meaning and the research does } \\
\text { allude to this. The central issue of } \\
\text { personal financial data may also } \\
\text { be considered a socio-historical } \\
\text { tool in the MM system. However } \\
\text { in the ISM this is not the case. }\end{array}$ \\
\hline
\end{tabular}




\begin{tabular}{|l|l|l|}
\hline & Case 1 & Case 2 \\
\hline $\begin{array}{l}\text { Studies development and change } \\
\text { (including historical, organisational, } \\
\text { and moment-to-moment change) \& } \\
\text { individual development. }\end{array}$ & $\begin{array}{l}\text { Change was the objective of the } \\
\text { facilitated adoption of AIS but the } \\
\text { need for deeper changes to } \\
\text { existing rules and norms } \\
\text { emerged. This was particularly } \\
\text { pertinent in this case study where } \\
\text { the history of the country and its } \\
\text { impact on the socio-economic } \\
\text { context of the micro-enterprises } \\
\text { received a lot of attention and had } \\
\text { shaped the current rules and } \\
\text { norms. }\end{array}$ & $\begin{array}{l}\text { This was limited by the fact that } \\
\text { this was not Action Research but } \\
\text { the recommendations were } \\
\text { change oriented. }\end{array}$ \\
\hline $\begin{array}{l}\text { People are active and knowing } \\
\text { agents but they act in sites that are } \\
\text { not necessarily of their choosing } \\
\text { with tools that constrain and afford } \\
\text { their actions. }\end{array}$ & $\begin{array}{l}\text { The agency and economic } \\
\text { circumstances of the entrepreneur } \\
\text { were a focus of the study. }\end{array}$ & $\begin{array}{l}\text { This was constrained by the } \\
\text { organisational view of the study. A } \\
\text { future study focussing on the user } \\
\text { of a mobile money system and } \\
\text { the agents who facilitate such a } \\
\text { system 'on the ground' would } \\
\text { make this insight from AT more } \\
\text { visible. }\end{array}$ \\
\hline $\begin{array}{l}\text { Methodologically, AT rejects } \\
\text { positivism in favour interpretivism, } \\
\text { and makes use of contextualist } \\
\text { methodologies. }\end{array}$ & $\begin{array}{l}\text { The study took place in the } \\
\text { community although not on the } \\
\text { premises of the micro-enterprises. }\end{array}$ & $\begin{array}{l}\text { The analysis was interpretivist } \\
\text { and focussed on work activities. It } \\
\text { used Uganda as the broader } \\
\text { context where the country's } \\
\text { existing laws and regulations had } \\
\text { a large influence on ISM. }\end{array}$ \\
\hline $\begin{array}{l}\text { Changes as driven by } \\
\text { contradictions which can arise } \\
\text { within and between systems. }\end{array}$ & $\begin{array}{l}\text { Contradiction, as well as } \\
\text { strengths were the focus of the } \\
\text { analysis. } \\
\text { contradictions that were } \\
\text { uncovered. }\end{array}$ \\
\hline
\end{tabular}

\section{Conclusion}

The primary strength of Activity Theory as a lens for analysis of qualitative data is its ability to highlight reasons for failure or disappointing performance and to encourage change or innovation. The contradictions or tensions may occur either between different activities, between an earlier version of an activity and a later version as the activity evolves, or within an activity (between the elements of that activity). However, the converse is also true. Evidence of strong relationships between activities or between the elements of an activity in a new system or pilot project can indicate that the activity or the sequence of activities (as in Case 1) or a number of activities carried out at the same time (as in Case 2), is likely to accomplish the desired object.

However, the presence of several particularly strong relationships within a group of activity systems can lead to stagnation. There was evidence from Case 2 that, where almost all the competitors in a particular sector are involved in activities that are largely the same, little improvement in the product or service offered will be evident. Such stagnation and lack of competitive advantage may occur if rules and regulations constrain the activity systems, if all the subjects use virtually the same technologies or if the environment has limited skills available, thereby causing division of labour to be similar for all competitor. However, the motive of the Subject (in Case 2 this was the MNOs) may be to keep things unchanged. It is therefore a conclusion from this paper that contradictions as well as strengths, together with the underlying motives encouraging or hindering innovation, need to be examined.

A more methodological advantage is that the analytical process related to AT can be structured using the activity system model but nevertheless, by focussing on the cultural and historical aspects while recognising the major role played by tools and the object, it can produce insights that are not obvious using other theoretical lenses or methodologies. This structure aids researchers who are uncertain how to analyse qualitative data effectively.

The question can be asked as to how AT differs from other approaches, e.g. a comprehensive process analysis, that will also take due account of differing cultures, behaviour, skills and so. This is an interesting question and is addressed here only briefly. There certainly are commonalities as several of these take the context into account. As noted earlier other approaches have been criticized on the grounds that they have too narrow a 
focus (fail to provide a holistic analysis of real-life situations). That they do not 'dig' sufficiently deeply into a social system, and are that deliberately seeking out contradictions is unique to AT.

The disciplinary origins of the approaches differ and thus the underlying world views are different. AT has origins in the humanities while process flow analysis or business reengineering developed as tools for business analysts and for business process redesign. The areas of interest highlighted by the methodologies are therefore also different and might focus more often on the different hierarchical levels identified in AT, namely, the activity, the action and the operation. An in-depth comparison between these would make an interesting follow up paper, with a co-author who is well-versed in process flow analysis or business reengineering. Activity Theory and Business Reengineering.

AT's strength lies in its ability to transform human activity through a mediated approach. As such AT can provide a theoretical framework which can possibly be utilised in business process reengineering and practice improvement in a business environment. The case studies reported on in this paper both focussed on activities rather than actions or operations, but a critique of those studies is that in many cases data collected really referred to actions and operations. However, the distinction between an action and an activity can become blurred. An operation is generally regarded as a process whereby incoming resources are transformed into out-going products / services by a series of activities or sub-processes. A clear understanding of the different levels may lead to a conclusion that AT analysis could be complemented by a comprehensive process analysis and that such a combination would be of value.

The primary objective for this paper was achieved in the discussion of the exiting literature and the discussion of the two case studies. The secondary objectives were demonstrated using the case studies both of which successfully did a critical analysis of qualitative data. It is believed that in both cases insights were obtained regarding the organisational changes resulting from the introduction of ICT-related tools and other artefacts to mediate a business activity or a series of activities even though the organisations were at different ends of the spectrum in terms of size. AT proved valuable in a study at macro-organisational level (across three large organisations in the same sector) and at micro-level. The research methodologies were also very different. In Case 1, participative action research was carried out whereas Case 2 was a descriptive case study.

\section{References}

Allen, D. K. et al. (2013) 'How should technology-mediated organizational change be explained? A comparison of the contributions of Critical Realism and Activity Theory', MIS Quarterly, 37(3), pp. 835-854. doi: $10.25300 / \mathrm{misq} / 2013 / 37.3 .08$.

Bagarukayo, E. et al. (2016) 'Activity Theory as a lens to understand how Facebook develops knowledge application skills', International Journal of Education and Development using Information and Communication Technology, 12(3), pp. 128-140. Available at: http://web.b.ebscohost.com/ehost/pdfviewer/pdfviewer?vid=19\&sid=321593de-9ee8-4d809612-5fdd98995fed\%40sessionmgr103.

Barab, S. A., Evans, M. A. and Baek, E. (2004) 'Activity theory as a lens for characterizing the participatory unit', in Jonassen, I. D. H. (ed.) Handbook of Research on Educational Communications and Technology. Washington DC: Association for Educational Communication and Technology, pp. 199-214.

Clemmensen, T., Kaptelinin, V. and Nardi, B. (2016) 'Making HCl theory work: an analysis of the use of activity theory in $\mathrm{HCl}$ research', Behaviour and Information Technology, 35(8), pp. 608-627. doi: 10.1080/0144929X.2016.1175507.

Engeström, Y. (1999) 'Activity Theory and Individual and Social Transformation', in Engeström, Y., Miettinen, R., and Punamäki-Gitai, R.-L. (eds) Perspectives on Activity Theory. Cambridge University, Cambridge, UK: Cambridge University Press, pp. 19-38. doi: 10.2307/259146.

Engeström, Y. (2001) 'Expansive learning at work: Toward an activity theoretical reconceptualization', Journal of Education and Work, 14(1), pp. 133-156. doi: 10.1080/13639080020028747.

Engeström, Y. (2010) 'Activity Theory and Learning at Work', in. SAGE Publication, pp. 74-89.

Foot, K. A. (2014) 'Cultural-Historical Activity Theory: Exploring a theory to inform practice and research', Journal of Human Behavior in the Social Environment, 24:3(July 2015), pp. 329-347. doi: 10.1080/10911359.2013.831011.

Forsgren, E. and Byström, K. (2018) 'Multiple social media in the workplace: Contradictions and congruencies', Information Systems Journal, 28(July), pp. 442-464. doi: 10.1111/isj.12156.

Hardman, J. (2005) 'Activity theory as a potential framework for technology research in an unequal terrain', South African Journal of Education, 19(2), pp. 378-392.

Harrington, D. and Kearney, A. (2011) 'The business school in transition: New opportunities in management development, knowledge transfer and knowledge creation', Journal of European Industrial Training, 35(2), pp. 116-134. doi: 10.1108/03090591111109334. 
Hasan, H. and Kazlauskas, A. (2014) 'Activity Theory: who is doing what, why and how', in Hasan, H. (ed.) Being Practical with Theory: A Window into Business Research. Wollongong, Australia: THEORI, pp. 9-14. Available at: http://eurekaconnection.files.wordpress.com/2014/02/p-09-14-activity-theory-theori-ebook-2014.pdf\%0AResearch.

Hashim, N. H. and Jones, M. L. (2007) 'Activity theory: A framework for qualitative analysis', International Qualitative Research Convention, pp. 3-5.

Jones, O. and Holt, R. (2008) 'The creation and evolution of new business ventures: An activity theory perspective', Journal of Small Business and Enterprise Development, 15(1), pp. 51-73. doi: 10.1108/14626000810850847.

Kang, M. D. Y. and Hovav, A. (2018) 'Benchmarking methodology for information security policy (BMISP): Artifact development and evaluation', Information Systems Frontiers, pp. 1-22. doi: 10.1007/s10796-018-9855-6.

Kanobe, F., Alexander, P. M. and Bwalya, K. J. (2017) 'Policies, regulations and procedures and their effects on mobile money systems in Uganda', Electronic Journal of Information Systems in Developing Countries, 83(1).

Karanasios, S. (2014a) 'Framing ICT4D research using Activity Theory : A match between the ICT4D field and theory ?', Information Technology \& International Development, 10(2), pp. 1-17.

Karanasios, S. (2014b) 'Mobile technology in mobile work: Contradictions and congruencies in activity systems', Eur J Inf Syst., 23(5), pp. 529-542. doi: 10.1057/ejis.2014.20.

Karanasios, S. (2018) 'Toward a unified view of technology and activity: The contribution of activity theory to information systems research', Information Technology and People, 31(1), pp. 134-155. doi: 10.1108/ITP-04-2016-0074.

Karanasios, S. and Allen, D. (2013) 'ICT for development in the context of the closure of Chernobyl nuclear power plant: An activity theory perspective', Information Systems Journal, 23(4), pp. 287-306. doi: 10.1111/isj.12011.

Karanasios, S. and Allen, D. (2018) 'Activity theory in Information Systems research', Information Systems Journal, 28(3), pp. 439-441. doi: 10.1111/isj.12184.

Kekwaletswe, R. M. and Lesole, T. (2016) ‘A framework for improving Business Intelligence through Master Data Management', Journal of South African Business Research, 2016(Article ID 473749), pp. 1-12. doi: 10.5171/2016.

Kelly, P. R. (2018) 'An activity theory study of data, knowledge, and power in the design of an international development NGO impact evaluation', Information Systems Journal, 28(3), pp. 465-488. doi: 10.1111/isj.12187.

Kizito, R. (2015) 'Structuring an Activity Theory-based framework for evaluating a science extended curriculum programme', South African Journal of Higher Education, 29(1), pp. 211-237.

Korpela, M., Mursu, A. and Soriyan, H. A. (2002) 'Information systems development as an activity', Computer Supported Cooperative Work, 11(1-2).

Kuutti, K. (1996) 'Activity Theory as a potential framework for human- computer interaction research', in Nardi, B. A. (ed.) Context and Consciousness: Activity Theory and Human Computer Interaction. Cambridge: MIS Press, pp. 17-44.

Lektorsky, V. A. (2009) 'Mediation as a means of collective activity', in Sannino, A., Daniels, H. \& Gutierrez, K. D. (ed.) Learning and Expanding with Activity Theory. New York: Cambridge University Press.

Malaurent, J. and Avison, D. (2016) 'Reconciling global and local needs: A canonical action research project to deal with workarounds', Information Systems Journal, 26(3), pp. 227-257. doi: 10.1111/isj.12074.

Marcandella, E. and Guèye, K. (2018) 'Tensions in collaborative innovation projects and higher-level learning', Learning Organization, 25(4), pp. 248-259. doi: 10.1108/TLO-06-2017-0066.

Mursu, A. et al. (2007) 'Activity Theory in Information Systems research and practice: Theoretical underpinnings for an Information Systems development model', Information Research, 12(3), pp. 1-21. doi: 311.

Mursu, A., Lyytinen, K. and Korpela, M. (2002) Information systems development in developing countries: Risk management and sustainability analysis in Nigerian software companies, JYVÄSKYLÄ STUDIES IN COOMPUTING 21. UNIVERSITY OF JYVÄSKYLÄ.

Mursu, A., Soriyan, A. and Korpela, M. (2003) 'ICT for development: Sustainable systems for local needs', in Proceedings of IFIP WG, pp. 199-210.

Nardi, B. A. (1996) 'Activity Theory and human-computer interaction', in Context and Consciousness: Activity Theory and Human-Computer Interaction, pp. 7-16. doi: 10.1207/s15327884mca0501_7.

Roth, W. M. and Lee, Y. J. (2007) “"Vygotsky's neglected Legacy”: Cultural-historical activity theory', Review of Educational Research, 77(2), pp. 186-232. doi: 10.3102/0034654306298273.

Sadok, M. and Welch, C. E. (2019) 'Achieving sustainable business systems through sociotechnical perspectives', in Proceedings of the 27th European Conference on Information Systems. Stockholm \& Uppsala, Sweden: AIS Electronic Library (AISeL), p. Paper 65. Available at: https://aisel.aisnet.org/ecis2019_rp Recommended.

Simeonova, B. (2018) 'Transactive memory systems and Web 2.0 in knowledge sharing: A conceptual model based on activity theory and critical realism', Information Systems Journal, 28(4), pp. 592-611. doi: 10.1111/isj.12147.

Spinuzzi, C. (2014) 'How nonemployer firms stage-manage ad hoc collaboration: An activity theory analysis', Technical Communication Quarterly, 23(2), pp. 88-114. doi: 10.1080/10572252.2013.797334.

Stuart, K. (2014) 'Activity theory as a reflective and analytic tool for action research on multi-professional collaborative practice', Reflective Practice. Routledge, 15(3), pp. 347-362. doi: 10.1080/14623943.2014.900007.

Toivanen, M. et al. (2004) 'Gathering, structuring and describing information needs in home care: a method for requirements exploration in a "gray area".', Studies in Health Technology and Informatics, 107(Pt 2), pp. $1398-1402$.

Weeger, A. and Haase, U. (2016) 'How contradictions facilitate evolutionary transformation: An exploration into the dynamics of business-IT alignment from the perspective of activity theory', in 24th European Conference on Information Systems, ECIS 2016. AIS Electronic Library (AISeL), p. Paper 173. Available at: http://aisel.aisnet.org/ecis2016_rp Recommended. 
White, G. R. T. and Cicmil, S. (2016) 'Knowledge acquisition through process mapping: Factors affecting the performance of work-based activity', International Journal of Productivity and Performance Management, 65(3), pp. 302-323. doi: 10.1108/IJPPM-01-2014-0007.

Zott, C. and Amit, R. (2017) 'Business model innovation: How to create value in a digital world', GfK Marketing Intelligence Review, 9(1), pp. 18-23. doi: 10.1515/gfkmir-2017-0003. 